\title{
Glucose Tolerance and Plasma Insulin in Newborn Infants of Normal and Diabetic Mothers
}

\author{
T.E. IsLES, M.Digkson and J.W.FARQUHAR ${ }^{[20]}$ \\ Department of Child Life and Health, University of Edinburgh, and the Simpson Memorial \\ Maternity Pavilion, The Royal Infirmary of Edinburgh (Scotland)
}

\begin{abstract}
Extract
Infants born to diabetic mothers remove glucose more rapidly from plasma than do infants of normal mothers. The glucose tolerance of normal newborns in the first hour after intravenous injection of glucose is poorer than in the child or adult. Infants of diabetic mothers have higher levels of insulin-like activity in plasma a few minutes after an intravenous glucose load than do normals. The rate of removal of glucose from plasma during the second hour after loading, however, is enhanced in infants of normal mothers; this correlates with the later peak levels of immunologically reactive insulin in the normal baby.

Glucose tolerance and levels of insulin in plasma were determined under identical conditions in the infants of 14 normal mothers, of 14 diabetic mothers who had received insulin, of 6 diabetic mothers who had not received insulin, and of one mother who had had glucosuria in pregnancy and whose baby looked like the infant of a diabetic mother.

Glucose tolerance was expressed as the 'total index' $(\mathrm{Kt})$, the percentage of glucose disappearing from the plasma in one minute. Insulin levels in plasma were determined by the method of HaLES and RANDle [9]. The Kt of infants of normal women (0.44 to 2.31, with a mean of 1.16) during the first hour after a glucose load differed little from that of infants of non-insulin-treated diabetic mothers (1.51 to 1.93 , with a mean of 1.31). The $\mathrm{K} t$ of both groups differed significantly from that of infants of insulin-treated diabetic mothers, in whom the $\mathrm{Kt}$ was in the range 0.83 to 5.78 , with a mean of 3.30 . In the second hour, however, the rate of glucose removal in both groups of infants of diabetic mothers appeared to fall, while in infants of normal mothers, the rate appeared to rise.

These observations on $\mathrm{Kt}$ correlate with changes in insulin levels in plasma of the normal and noninsulin-treated diabetic groups. Although individual differences existed within the groups, the mean for normals rose from $49 \mu \mathrm{U} / \mathrm{ml}$ of plasma before glucose-loading to 139 at two minutes after. The level then fell, but climbed again to reach a value of $229 \mu \mathrm{U} / \mathrm{ml}$ at one hour. In contrast, the mean for the diabetic group rose from a value of 34 prior to loading to one of $208 \mu \mathrm{U} / \mathrm{ml}$ two minutes after loading. There was, however, little if any second peak.

The presence of antiinsulin antibodies makes impossible the accurate measurement of insulin levels in plasma of babies of mothers who have been treated with insulin; in one case, however, treatment had been so brief that no antibody was formed. This baby showed a high but ephemeral insulin response to the glucose load.

The infant who looked like an infant of a diabetic mother and whose mother was found to have had persistent glucosuria in pregnancy had, in the absence of insulin antibody, the highest insulin response observed.
\end{abstract}




\section{Speculation}

In the first hours of life, insulin is released in response to a glucose load, but the size and speed of the response suggest that it simply reflects the glucose levels to which the infant's pancreas has been submitted in utero and has no specific relation to the diabetic status of the mother.

Glucose is readily removed from plasma as a result of the release of insulin, yet the opposing mechanisms for increasing plasma levels of glucose are relatively ineffective at this age, although the neonatal liver contains glycogen. Glycogen can be released readily by administering glucagon, suggesting that the appropriate metabolic pathways are functional.

When insulin response to glucose is delayed because intrauterine stimulation of the pancreas has been small, the hormone is nonetheless effective in lowering plasma levels of glucose. These observations reported suggest that although the metabolic pathways for glucose homeostasis exist in the newbu:n, the hormonal mechanisms for controlling these are inappropriately invoked.

\section{Introduction}

Infants of diabetic mothers (IDM) become hypoglycemic in the period immediately following birth more quickly than do infants of normal mothers (INM) [6, 8]. Differences in glucose tolerance between these two groups were shown by BAIRD and Farquhar [2], although JøRGENSEN et al. [11] were unable to confirm the finding that IDM remove an intravenously administered glucose load more rapidly than do INM. The present study documents the changes occurring in immunologically reactive insulin levels in the plasma following hyperglycemic stimulation in newborn infants of normal mothers, of insulin-treated diabetic mothers, and in the less common infants of insulin-independent mothers. It relates these changes to the removal of glucose from plasma.

\section{Patients and Mothers}

All babies studied were born at the Simpson Memorial Maternity Pavilion; pertinent clinical data are given in table I. The 14 normal babies were born to women in whom diabetes mellitus had been excluded as carefully as possible by examination of family history, past obstetric record, many urine specimens at regular intervals during pregnancy and, in most cases, by glucose tolerance tests. The infants of diabetic women were born to 6 mothers whose diabetes was controlled without insulin and to 14 mothers who did receive insulin. The diabetic group that had not had insulin included two patients, No. 310 and No. 320, who had been treated with tolbutamide and diet, and four who had been controlled with diet alone. In the insulin-treated group, one mother, No.331, had received insulin for only two weeks. One baby, No.3534/66, was originally thought to be a normal baby, but had the clinical appearance suggestive of diabetes. Routine scrutiny of the mother's case record revealed that she had had repeated antenatal glucosuria, but had noted neither thirst nor polyuria. A glucose tolerance test performed on the mother five months later was reported to be entirely normal.

Each baby was given a placental transfusion [16]. Cord blood was taken for determination of glucose and insulin levels, and the babies were placed immediately in an incubator at an environmental temperature in the critical range for maturity [14]. Further blood samples for glucose levels were taken from the warm heel at 30 , 60 and 90 minutes after birth. The umbilical vein was then catheterized to the nearest point from which blood could be readily obtained. This point was always 7.5 $\mathrm{cm}$ or less from the anterior abdominal wall. Blood was taken at 120 minutes of age for determinations of glucose and insulin levels in plasma. The baby was immediately given dextrose $(0.5 \mathrm{~g} / \mathrm{kg}$ of body weight) by rapid intravenous injection and the catheter was flushed with heparinized saline. Specimens of blood were taken for determination of glucose and insulin levels at precisely 2, 5, 10, 20,30, 40,60, 75, 90 and 120 minutes after the dextrose injection. Each volume removed was immediately replaced exactly with heparinized saline. Hemoglobin values were determined at 2, 3, 4 and 6 hours of age and on the following morning. No significant fall in hemoglobin values occurred, and all infants were reexamined for sequelae in subsequent months.

The procedure was carefully explained to all mothers before the babies were born and was pursued only when the mothers freely consented. The babies received glucose injections and were catheterized under aseptic conditions by J.W.F. In addition, all observations on clinical conditions were made by J.W.F. The cord stump was protected with 'Polybactrin' [17], and each baby received cloxacillin and ampicillin in therapeutic doses for three days following study. As previ- 
ously noted [8], the IDM were rather less mature but were as heavy as the INM.

Levels of insulin in plasma were measured by the immunoassay method of Hales and RANDLE $[9,18]$. The method used is fully described in the Radiochemical Centre Data Sheet 5581 [4]. The ${ }^{125} \mathrm{I}$-insulin was obtained from the Radiochemical Centre, Amersham, Bucks., England, and had a specific activity of not less than $50 \mu \mathrm{c} / \mu \mathrm{g}$. The insulin-binding reagent was prepared at the Wellcome Research Laboratories. The sensitivity of the assay system was $0.4 \mu \mathrm{U}$ insulin, and the standard deviation over the concentration range 0.4 to $10 \mu \mathrm{U}$ insulin was 3 to 4 percent of the mean.

The binding of ${ }^{125} \mathrm{I}$-insulin by plasma proteins was determined by measuring the relative proportions of added radioactive insulin present in the protein fraction and at the point of origin following electrophoresis of the plasma on Whatman $3 \mathrm{MC}$ filter paper strips using $0.072 \mathrm{M}$ barbitone buffer, $\mathrm{pH} 8.6$, as solvent $[10,15]$.

Glucose in plasma was assayed by the method described by RAABO and TERKILDSEN [12] using glucose oxidase. The assay was carried out without prior precipitation of plasma proteins, except in the rare circumstance of excessive hemolysis. An excess of glucose oxidase eliminated any inhibitory effect of the fluoride used to prevent glycolysis. The standard deviation of this mcthod was $\pm 1.7 \mathrm{mg} / 100 \mathrm{ml}$ at the level of 100 $\mathrm{mg} / 100 \mathrm{ml}$ and $\pm 0.6 \mathrm{mg} / 100 \mathrm{ml}$ at the level of $10 \mathrm{mg} /$ $100 \mathrm{ml}$.

Glucose tolerance was measured by a technique of rapid single intravenous injection of glucose $[1,5]$. The rate of removal of glucose from the plasma was determined from a semilogarithmic plot of total glucose concentration against time and is expressed as the 'total index' (Kt), the percentage of glucose disappearing in one minute. The infants received a standardized glucose load of $0.5 \mathrm{~g}$ glucose $/ \mathrm{kg}$ of body weight.

All procedures involving measurements and calculations were carried out by the staff of the Biochemical Research Laboratory of the Department of Child Life and Health in the University of Edinburgh.

The significance of differences between mean values was tested by Student's t-test.

\section{Results}

\section{Levels of Glucose in Plasma and Glucose Tolerance}

In the groups of infants studied, levels of glucose in plasma during the period immediately preceding the administration of glucose by intravenous injection tended to be low. In the infants of diabetic mothers, levels below $20 \mathrm{mg} / 100 \mathrm{ml}$ were very common. The mean values for glucose levels in plasma are shown in table II, but the detailed findings are dealt with more fully elsewhere [8].

Following the administration of glucose to the infants, significant differences $(0.005>\mathrm{P}>0.001$ to $\mathrm{P}<0.001$ ) were found in the levels of glucose in plasma between infants of normal mothers and infants of insulin-treated diabetic mothers during the 120 minutes of the study. No such significant differences were found between the infants of normal mothers and the infants of diabetic mothers treated by diet alone or diet and oral hypoglycemic agents (table III, fig. 1). The glucose level at two minutes after the glucose injection was below $200 \mathrm{mg} / 100 \mathrm{ml}$ in all of the infants of insulin-dependent diabetic mothers. This low maximum glucose level could not be explained entirely by the lower levels in plasma prior to injection. The glucose levels in some of the infants of the insulintreated diabetic mothers returned to very low levels, and in two individuals were below $20 \mathrm{mg} / 100 \mathrm{ml} 30$ minutes after the glucose had been given. Neither the infants of the normal mothers nor those of the diabetic mothers who had had no therapeutic insulin reached such low levels during the period of study (table III).

These differences between the groups are reflected in the values calculated for the rates of removal of glucose from the plasma. The determination of the 'total index' or rate constant $\mathrm{Kt}$ for removal of glucose is re-

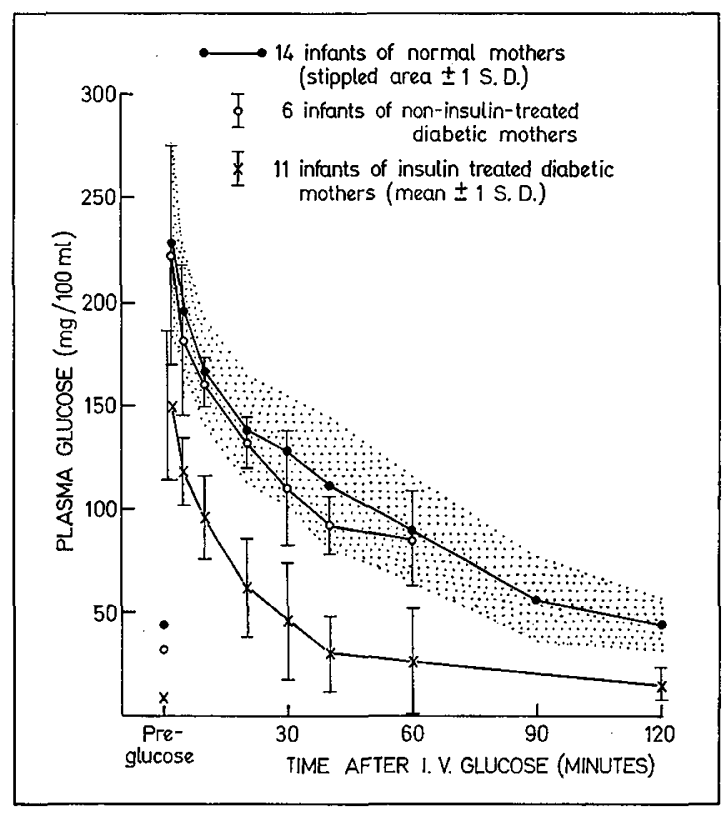

Fig. 1. Mean plasma glucose levels following intravenous glucose $(0.5 \mathrm{~g} / \mathrm{kg}$ body weight $)$ injected at 120 minutes of life. 
Table $I$. Clinical data of the babies studied

\begin{tabular}{|c|c|c|c|c|c|}
\hline & Case No. & $\begin{array}{l}\text { Age of } \\
\text { mother } \\
\text { (years) }\end{array}$ & $\begin{array}{l}\text { Mode of } \\
\text { delivery }\end{array}$ & $\begin{array}{l}\text { Maturity of } \\
\text { baby } \\
\text { (weeks) }\end{array}$ & $\begin{array}{l}\text { Weight of } \\
\text { baby } \\
\text { (g) }\end{array}$ \\
\hline \multirow[t]{14}{*}{ Infants of normal mothers } & $3374 / 66$ & 18 & vaginal & 41 & 2693 \\
\hline & $2751 / 66$ & 30 & vaginal & 40 & 3827 \\
\hline & $3490 / 66$ & 23 & vaginal & 39 & 3629 \\
\hline & $3530 / 66$ & 26 & vaginal & 42 & 3459 \\
\hline & $3563 / 66$ & 26 & vaginal & 40 & 3856 \\
\hline & $3611 / 66$ & 18 & vaginal & 42 & 3515 \\
\hline & $4516 / 66$ & 28 & vaginal & 41 & 3742 \\
\hline & $4477 / 66$ & 26 & vaginal & 39 & 3402 \\
\hline & $4680 / 66$ & 27 & vaginal & 41 & 3799 \\
\hline & $4704 / 66$ & 25 & vaginal & 39 & 3374 \\
\hline & $2277 / 65$ & 29 & vaginal & 40 & 3402 \\
\hline & $2936 / 65$ & 22 & vaginal & 40 & 3430 \\
\hline & $3008 / 65$ & 22 & vaginal & 39 & 3600 \\
\hline & $3123 / 65$ & 29 & vaginal & 39 & 3685 \\
\hline \multirow{6}{*}{$\begin{array}{l}\text { Infants of diabetic mothers } \\
\text { (non-insulin-treated) }\end{array}$} & 319 & 31 & vaginal & 37 & 3402 \\
\hline & 320 & 30 & vaginal & 36 & 3941 \\
\hline & 322 & 30 & vaginal & 39 & 3490 \\
\hline & 310 & 28 & $\mathrm{C} / \mathrm{S}$ & 33 & 2055 \\
\hline & 309 & 24 & vaginal & 35 & 3841 \\
\hline & 334 & 24 & vaginal & 38 & 3515 \\
\hline \multirow{11}{*}{$\begin{array}{l}\text { Infants of diabetic mothers } \\
\text { (insulin-treated) }\end{array}$} & 331 & 27 & $\mathrm{C} / \mathrm{S}$ & 37 & 4080 \\
\hline & 296 & 22 & vaginal & 37 & 3685 \\
\hline & 297 & 33 & $\mathrm{G} / \mathrm{S}$ & 33 & 2807 \\
\hline & 298 & 30 & $\mathrm{G} / \mathrm{S}$ & 36 & 3572 \\
\hline & 299 & 26 & $\mathrm{C} / \mathrm{S}$ & 35 & 3203 \\
\hline & 300 & 23 & $\mathrm{C} / \mathrm{s}$ & 36 & 2877 \\
\hline & 302 & 27 & $\mathrm{C} / \mathrm{S}$ & 36 & 4110 \\
\hline & 307 & 33 & vaginal & 37 & 3685 \\
\hline & 327 & 25 & $\mathrm{C} / \mathrm{S}$ & 36 & 4780 \\
\hline & 328 & 29 & $\mathrm{C} / \mathrm{S}$ & 36 & 3700 \\
\hline & 329 & 34 & $\mathrm{C} / \mathrm{S}$ & 35 & 2693 \\
\hline $\begin{array}{l}\text { Infant of mother with glucosuria } \\
\text { during pregnancy }\end{array}$ & $3534 / 66$ & 35 & vaginal & 37 & 3232 \\
\hline
\end{tabular}

lated to the total plasma glucose concentration at each time of sampling, rather than to the increment in the plasma glucose over the glucose level determined immediately before the administration of the glucose. The values used in the calculations were those found in the plasma of blood obtained through the catheter in the umbilical vein. The values found in the first 10 minutes following administration of glucose were disregarded in calculating the index. Essentially the same results were obtained when calculations were based on samples obtained from a heel stab, although the Kt values were lower on the average by 0.09 in the infants of normal mothers and by 0.64 in the infants of the insulin-treated diabetic mothers. This difference reflects the higher glucose levels in the umbilical vein over the first 10 to 20 minutes of the test. A similar sharp rise and rapid fall in the glucose values over the first 10 minutes of the test were found in the plasma from both heel and umbilical vein.

When the removal rate constants ('increment index') were calculated from the increment plasma glucose values, essentially the same pattern of results was found as with 'total index', but the increment method tended to obscure later changes in the rate constants which were shown to be important. Hence only $\mathrm{Kt}$ values are quoted.

The values for $\mathrm{Kt}$ were calculated over the two periods 10 to 60 minutes and 60 to 120 minutes after the 
Table II. Levels of glucose in plasma during the first two hours of life

\begin{tabular}{|c|c|c|c|c|c|c|}
\hline & & \multicolumn{5}{|c|}{ Time of specimen (minutes after birth) } \\
\hline & & cord & 30 & 60 & 90 & 120 \\
\hline \multirow[t]{4}{*}{ Infants of normal mothers } & mean glucose $(\mathrm{mg} / 100 \mathrm{ml})$ & 84 & 49 & 38 & 36 & 44 \\
\hline & standard deviation & \pm 16 & \pm 17 & \pm 18 & \pm 13 & \pm 20 \\
\hline & number studied & & & 14 & 14 & 14 \\
\hline & range & $65-119$ & $30-80$ & $12-75$ & $21-69$ & $19-91$ \\
\hline \multirow{4}{*}{$\begin{array}{l}\text { Infants of diabetic mothers } \\
\text { (non-insulin-treated) }\end{array}$} & mean glucose $(\mathrm{mg} / 100 \mathrm{ml})$ & 85 & 35 & 23 & 21 & 22 \\
\hline & standard deviation & \pm 28 & \pm 30 & \pm 16 & \pm 8 & \pm 8 \\
\hline & number studied & 6 & 6 & 6 & 6 & 6 \\
\hline & range & $55-124$ & $9-83$ & $7-51$ & $11-34$ & $14-37$ \\
\hline \multirow{4}{*}{$\begin{array}{l}\text { Infants of diabetic mothers } \\
\text { (insulin-treated) }\end{array}$} & mean glucose $(\mathrm{mg} / 100 \mathrm{ml})$ & ) 130 & 35 & 12 & 7 & 8 \\
\hline & standard deviation & \pm 39 & \pm 19 & \pm 11 & \pm 5 & \pm 7 \\
\hline & number studied & 14 & 13 & 14 & 14 & 14 \\
\hline & range & $70-202$ & $0-71$ & $0-42$ & $0-17$ & $0-27$ \\
\hline
\end{tabular}

glucose administration, and these are recorded in table IV and figure 2. The calculation of $\mathrm{Kt}$ requires, by definition, an exponential decrease in glucose level, and over the period 60-120 minutes such an exponential fall has not been shown to occur. Possibly there is not a single rate of glucose removal but rather a gradation of changes. However, Kt has been used by Bowre et al. [3] to indicate the changes in the rate of glucose removal from the first to the second hour of an intravenous glucose tolerance test.

In a similar manner, in this study, the Kt values have been useful in contrasting changes in rate from the first to the second hour, but because of the lack of certainty about the exponential character of the glucose decrease in the second period and because of the relatively small number of observations made in this period in this study, the calculated $\mathrm{Kt}$ value is here referred to as the 'apparent Kt'. At least three glucose values were available for each 'apparent $\mathrm{Kt}$ ' calculated.

When a value is not quoted for the period $60-120$ minutes, there was either no data available or, in the case of some of the infants of the insulin-treated mothers, the fall in plasma glucose had been so rapid over the first 60 minutes of the test that the Kt could not be calculated for the second period.

From table IV it can be seen that in nine (69\%) of
Fig. 2. Removal rate constants $(\mathrm{Kt})$ for plasma glucose following intravenous glucose.

Individual values and the mean values \pm 1 standard deviation are shown.

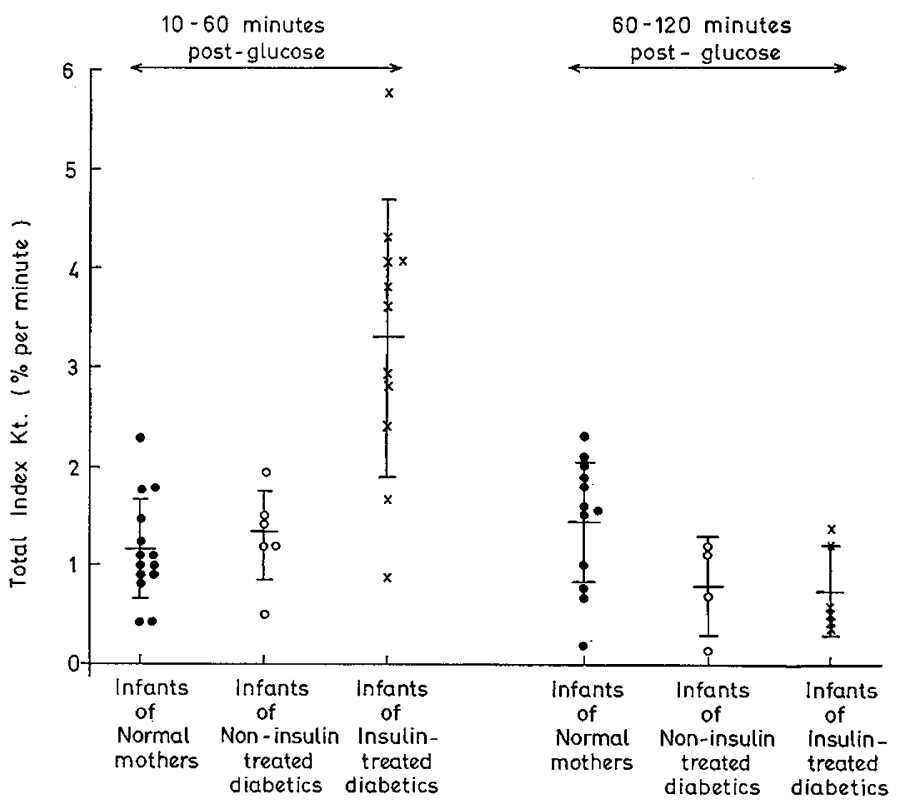


the infants of normal mothers, an increase in the rate of glucose removal was found after the first 60 minutes of the test had elapsed. In the period 60-120 minutes after glucose injection, the rate of glucose removal for the infants of diabetic mothers tended to diminish.

It is noteworthy that while for the first 60 minutes the $\mathrm{Kt}$ values of the infants of the non-insulin-treated mothers are not significantly different from the values found for the infants of normal mothers, they resemble more closely the values found for the infants of the insulin-treated mothers in the second hour of the test. This latter group is the one which they resemble closely in the period preceding the administration of the glucose load.

\section{Plasma Insulin Levels}

Levels of insulin in plasma were determined in the infants of normal and non-insulin-treated diabetic mothers before and during the intravenous glucose tolerance test. Because of the interference by maternal antibodies to insulin in the immunoassay of insulin, values obtained in the infants of insulin-treated diabetic mothers who have developed such antibodies are of doubtful value [10] and are not included. Only one of our group of infants of insulin-treated diabetic mothers had no antiinsulin antibodies; this mother had received insulin for only two weeks.

There was remarkable individual variation in the insulin response to the glucose load in the infants of normal mothers. In 8 of the 10 cases in which insulin was assayed, the administration of glucose produced an immediate insulin response; although in only three cases was this response large. A much more striking feature of this group was the high insulin level found at 60 minutes after glucoseinjection, with the maximum being found at 20,30,60 or 75 minutes in different individuals. Most babies exhibited more than one peak insulin value (table $\mathrm{V}$ ).

The infants of the insulin-independent diabetic mothers responded more uniformly to the glucose load, and all exhibited an insulin response two minutes after receiving glucose, the increase over the preglucose level being from 4- to 38-fold. With one exception (Baby No.334), the two-minute value was also the highest level attained, although in some cases secondary minor peak values were also found between 30 and 75 minutes after the glucose injection (table $\mathrm{V}$ ). The mean values for the insulin levels in plasma in the groups studied are shown in figure 3 and table $\mathrm{V}$.

Maternal antibodies to insulin which interfere with the immunoassay of insulin were not present in the cord blood plasma in those infants in whom plasma insulin levels were determined. Negligible amounts of radioactive insulin were bound to the plasma proteins (table VI). This finding, together with the low preglucose 


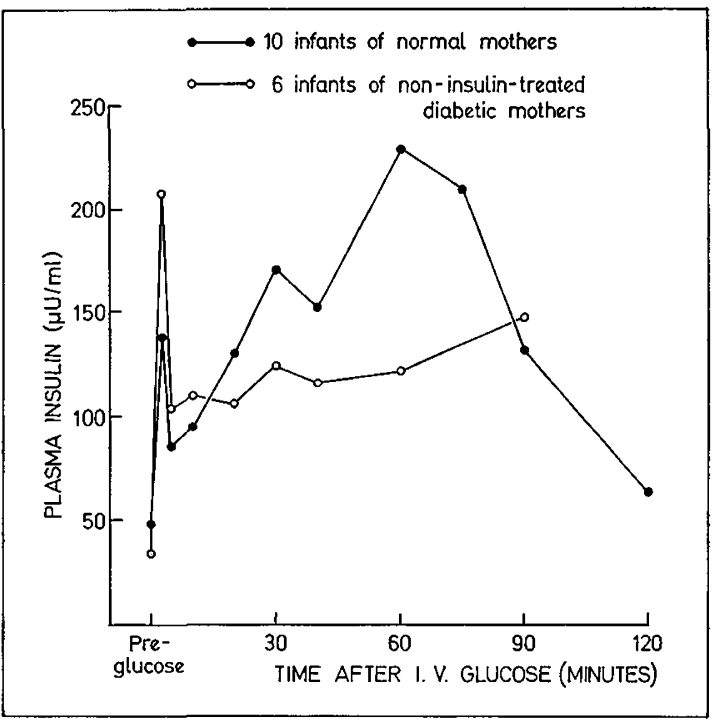

Fig. 3. Mean plasma insulin levels following intravenous glucose $(0.5 \mathrm{~g} / \mathrm{kg}$ body weight).

values for insulin and the inherent specificity of the immunoassay, suggests that the changes produced in response to a glucose load are in fact due to the release of insulin.

\section{Glucose Tolerance and Plasma Insulin}

The rate of glucose removal from the plasma of the infants of normal mothers usually increased 60 minutes or so after glucose injection; in general, this increased rate was accompanied by an increase in the level of insulin in plasma. An increase in 'apparent $\mathrm{K} t$ ' and the magnitude of the increase depended upon whether there had been an initial insulin response to glucose found in the two-minute specimen, upon the size of such a response, and upon the size of a subsequent rise at about 60 minutes. The higher the intial response, the less likelihood there seemed to be of an increase in the 'apparent $\mathrm{Kt}$ ' value after 60 minutes (tables IV and V).

When there was no secondary increase in insulin, there was no increase in the rate of glucose removal after 60 minutes, but an increase in the rate was possible when a high initial insulin response was followed by an even higher secondary response, as occurred in Baby No.334 (tables IV and V).

All the infants of the insulin-independent diabetic mothers showed high initial responses to the glucose load except Baby No.310, who showed only a four-fold increase. Where the rate of glucose removal did not change appreciably (Baby No.319), high insulin levels were maintained, with the highest level at two minutes after glucose. In two cases (Babies No.322 and No.309),
Table IV. Removal rate constants for plasma glucose following I.V. glucose load

\begin{tabular}{|c|c|c|c|}
\hline & \multicolumn{3}{|c|}{ Rate constant $(\mathrm{Kt})$ 'Apparent $\mathbf{K t}$ ' } \\
\hline & Case No. & $\begin{array}{l}10-60 \mathrm{~min} \\
\text { after } \\
\text { glucose load }\end{array}$ & $\begin{array}{l}60-120 \mathrm{~min} \\
\text { after } \\
\text { glucose load }\end{array}$ \\
\hline $\begin{array}{l}\text { Infants of } \\
\text { normal } \\
\text { mothers }\end{array}$ & $\begin{array}{l}3374 / 66 \\
2751 / 66 \\
3490 / 66 \\
3530 / 66 \\
3563 / 66 \\
3611 / 66 \\
4516 / 66 \\
4477 / 66 \\
4680 / 66 \\
4704 / 66 \\
2277 / 65 \\
2936 / 65 \\
3008 / 65 \\
3123 / 65 \\
\text { mean } \\
\text { SD } \\
\text { range }\end{array}$ & $\begin{array}{c}1.00 \\
1.12 \\
1.11 \\
0.44 \\
0.92 \\
2.31 \\
0.88 \\
1.75 \\
0.98 \\
1.22 \\
1.78 \\
1.43 \\
0.46 \\
0.85 \\
1.16 \\
\pm 0.51 \\
0.44-2.31\end{array}$ & $\begin{array}{l}1.54 \\
2.07 \\
1.80 \\
1.51 \\
1.87 \\
2.31 \\
1.02 \\
1.40 \\
2.01 \\
1.55 \\
0.21 \\
0.68 \\
0.77 \\
- \\
1.44 \\
\pm 0.61 \\
0.21-2.31\end{array}$ \\
\hline $\begin{array}{l}\text { Infants of } \\
\text { diabetic } \\
\text { mothers } \\
\text { (non-insulin } \\
\text { treated) }\end{array}$ & $\begin{array}{l}319 \\
320 \\
322 \\
310 \\
309 \\
334 \\
\text { mean } \\
\mathrm{SD} \\
\text { range }\end{array}$ & $\begin{array}{c}1.24 \\
1.93 \\
1.24 \\
1.49 \\
1.43 \\
0.51 \\
1.31 \\
\pm 0.47 \\
0.51-1.93\end{array}$ & $\begin{array}{l}1.13 \\
- \\
0.68 \\
- \\
0.16 \\
1.19 \\
0.79 \\
\pm 0.48 \\
0.16-1.19\end{array}$ \\
\hline $\begin{array}{l}\text { Infants of } \\
\text { diabetic } \\
\text { mothers } \\
\text { (insulin } \\
\text { treated) }\end{array}$ & $\begin{array}{l}331 \\
296 \\
297 \\
298 \\
299 \\
300 \\
302 \\
307 \\
327 \\
328 \\
329 \\
\text { mean } \\
\text { SD } \\
\text { range }\end{array}$ & $\begin{array}{r}0.83 \\
1.61 \\
3.85 \\
4.33 \\
2.89 \\
2.39 \\
4.08 \\
5.78 \\
3.55 \\
2.95 \\
4.08 \\
3.30 \\
\pm 1.37 \\
0.83-5.78\end{array}$ & $\begin{array}{l}0.36 \\
0.58 \\
- \\
- \\
0.52 \\
0.45 \\
- \\
- \\
1.41 \\
1.24 \\
- \\
0.76 \\
\pm 0.45 \\
0.36-1.41\end{array}$ \\
\hline
\end{tabular}

${ }^{1}$ See text for explanation of term 'apparent $\mathrm{Kt}^{\prime}$. 
Table $V$. Level of insulin in plasma in response to i.v. glucose load $(0.5 \mathrm{~g} / \mathrm{kg}$ body weight)

\begin{tabular}{|c|c|c|c|c|c|c|c|c|c|c|c|c|c|}
\hline \multirow{2}{*}{\multicolumn{2}{|c|}{$\begin{array}{c}\text { Time of specimen } \\
\text { (in minutes post-glucose) }\end{array}$}} & \multicolumn{12}{|c|}{ Plasma insulin $(\mu \mathrm{U} / \mathrm{ml}$ plasma $)$} \\
\hline & & $\begin{array}{l}\text { Pre- } \\
\text { glucose }\end{array}$ & 0 & 2 & 5 & 10 & 20 & 30 & 40 & 60 & 75 & 90 & 120 \\
\hline \multirow{14}{*}{$\begin{array}{l}\text { Infants of } \\
\text { normal } \\
\text { mothers }\end{array}$} & Case No. & & \multirow{9}{*}{ 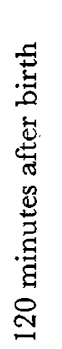 } & & & & & & & & & & \\
\hline & $3374 / 66$ & 49 & & 88 & 72 & 75 & 76 & 115 & 122 & 162 & - & 72 & 42 \\
\hline & $2751 / 66$ & 59 & & 127 & 85 & 72 & 105 & 147 & 92 & 155 & - & 62 & 50 \\
\hline & $3490 / 66$ & 37 & & 68 & 42 & 57 & 70 & 84 & 79 & 140 & - & 75 & 67 \\
\hline & $3530 / 66$ & 38 & & 35 & 45 & 60 & 88 & 168 & 200 & 365 & - & 325 & 63 \\
\hline & $3563 / 66$ & 25 & & 66 & 62 & 83 & 132 & 176 & 287 & 385 & - & 182 & 176 \\
\hline & $3611 / 66$ & 60 & & 320 & 112 & 118 & 124 & 156 & 134 & 80 & - & 80 & 38 \\
\hline & $4516 / 66$ & 58 & & 80 & - & 58 & 86 & 164 & - & 74 & 54 & 52 & 34 \\
\hline & $4477 / 66$ & 30 & & - & 178 & 96 & 100 & - & - & 50 & 64 & 52 & 37 \\
\hline & $4680 / 66$ & 25 & \multirow{14}{*}{ 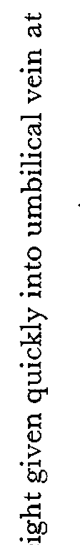 } & 21 & - & 72 & 180 & 245 & - & 405 & 167 & 155 & - \\
\hline & $4704 / 66$ & 88 & & 450 & - & 260 & 335 & 285 & - & 475 & 560 & 265 & - \\
\hline & mean & 49 & & 139 & 85 & 95 & 130 & 171 & 152 & 229 & 211 & 132 & 63 \\
\hline & & \pm 19 & & \pm 146 & \pm 48 & \pm 183 & \pm 79 & \pm 61 & \pm 78 & \pm 160 & - & \pm 97 & \pm 47 \\
\hline & range & $25-88$ & & $21-450$ & $42-178$ & $57-260$ & $70-335$ & $84-285$ & $79-287$ & $50-475$ & $54-560$ & $52-325$ & $34-167$ \\
\hline \multirow{9}{*}{$\begin{array}{l}\text { Infants of } \\
\text { diabetic } \\
\text { mothers } \\
\text { (non-insulin- } \\
\text { treated) }\end{array}$} & 319 & 64 & & 360 & 175 & 220 & 235 & 245 & 195 & 290 & - & 220 & 175 \\
\hline & 320 & 84 & & 304 & 242 & 198 & 200 & 278 & 200 & 108 & - & - & - \\
\hline & 322 & 32 & & 136 & 44 & 40 & 66 & 50 & 50 & 88 & - & 48 & - \\
\hline & 310 & 11 & & 47 & 37 & - & - & 12 & - & - & - & - & - \\
\hline & 309 & 5 & & 190 & 115 & 72 & 39 & - & 19 & 28 & - & - & 29 \\
\hline & 334 & 50 & & 108 & 70 & 80 & 52 & 114 & - & 164 & 296 & 280 & - \\
\hline & mean & 34 & & 208 & 104 & 110 & 106 & 124 & 116 & 122 & - & 148 & 102 \\
\hline & & \pm 29 & & \pm 119 & \pm 84 & \pm 79 & \pm 95 & \pm 112 & \pm 95 & \pm 95 & - & \pm 120 & - \\
\hline & range & $5-84$ & & $47-360$ & $37-242$ & $40-220$ & $39-235$ & $12-278$ & $\overline{19}-200$ & $28-290$ & - & $\overrightarrow{48}-280$ & - \\
\hline $\begin{array}{l}\text { Infant of } \\
\text { diabetic mother } \\
\text { treated with } \\
\text { insulin for two } \\
\text { weeks only }\end{array}$ & 331 & s. & \multirow{2}{*}{$\begin{array}{l}0 \\
3 \\
0 \\
0 \\
0 \\
0 \\
00 \\
00 \\
00 \\
00 \\
0 \\
0 \\
0 \\
0 \\
0 \\
0 \\
3 \\
0 \\
00\end{array}$} & 312 & 48 & 48 & 46 & 45 & - & 54 & 38 & 44 & - \\
\hline $\begin{array}{l}\text { Infant of } \\
\text { mother with } \\
\text { pregnancy } \\
\text { glucosuria }\end{array}$ & $3534 / 66$ & 165 & & 4000 & 775 & 710 & 500 & 225 & 180 & 135 & - & 120 & - \\
\hline
\end{tabular}


when the peak insulin value at two minutes fell to low levels at 60 minutes, the rate of glucose removal decreased in the second half of the test, but when the highest insulin value was found at 75 minutes (Baby No.334), the 'apparent Kt' increased (tables IV and V).

The insulin response to a glucose load by infants of insulin-treated diabetic mothers was shown in an earlier study [10] to be single-phased, with the maximum release of insulin at two minutes after glucose injection. The increase in insulin level was accompanied by a very rapid rate of glucose removal over the first 60 minutes, but the rate diminished over the second hour after glucose injection in those infants in whom glucose levels were not already very low (table $\mathrm{V}$ ).

The one infant (Baby No. 331), whose mother was receiving insulin but who had not at the time of delivery formed insulin antibodies, exhibited a large but tran-

Table VI. ${ }^{125} \mathrm{I}$-Insulin binding of cord blood plasma

\begin{tabular}{|c|c|c|}
\hline . & Case No. & $\begin{array}{l}\% \text { radio- } \\
\text { activity bound } \\
\text { by plasma } \\
\text { proteins } \\
\text { (paper } \\
\text { chromato- } \\
\text { graphy) } \\
\end{array}$ \\
\hline $\begin{array}{l}\text { Infants of normal } \\
\text { mothers }\end{array}$ & $\begin{array}{l}3374 / 66 \\
2751 / 66 \\
3490 / 66 \\
3530 / 66 \\
3563 / 66 \\
3611 / 66 \\
4516 / 66 \\
4477 / 66 \\
4680 / 66 \\
4704 / 66 \\
\text { mean }\end{array}$ & $\begin{array}{l}2.9 \\
3.6 \\
2.6 \\
5.8 \\
4.3 \\
5.9 \\
8.4 \\
8.1 \\
4.2 \\
4.6 \\
5.0 \\
\end{array}$ \\
\hline $\begin{array}{l}\text { Infants of diabetic } \\
\text { mothers (non-insulin } \\
\text { treated) }\end{array}$ & $\begin{array}{l}319 \\
320 \\
322 \\
310 \\
309 \\
334 \\
\text { mean }\end{array}$ & $\begin{array}{l}5.4 \\
5.1 \\
5.5 \\
6.2 \\
3.2 \\
6.5 \\
5.3\end{array}$ \\
\hline $\begin{array}{l}\text { Infant of diabetic } \\
\text { mother treated with } \\
\text { insulin for two weeks } \\
\text { only }\end{array}$ & 331 & 4.9 \\
\hline $\begin{array}{l}\text { Infant of mother with } \\
\text { pregnancy glucosuria }\end{array}$ & $3534 / 66$ & 5.0 \\
\hline
\end{tabular}

sient increase in insulin level two minutes after receiving the glucose. This rapid increase in insulin level did not result in a rapid removal of glucose, the $\mathrm{Kt}$ value being only 0.83 ; this decreased to 0.36 in the second hour.

Another atypical case was that of Baby No. 3534/66, whose mother was not being treated as a diabetic but who had glucosuria during pregnancy. She had received no prenatal glucose infusion. After birth, the plasma glucose levels in the baby at $30,60,90$ and 120 minutes were $5,11,15$ and $11 \mathrm{mg} / 100 \mathrm{ml}$ respectively. Following the administration of glucose, the glucose levels in plasma rose to $154 \mathrm{mg} / 100 \mathrm{ml}$, but within one hour had fallen to $8 \mathrm{mg} / 100 \mathrm{ml}$. No antibodies to insulin could be detected in the plasma, only 5 percent of the radioactive insulin migrating with the plasma proteins, yet the preglucose insulin level was high $(165 \mu \mathrm{U} / \mathrm{ml})$ and rose on administration of glucose to the colossal level of $4,000 \mu \mathrm{U} / \mathrm{ml}$ (table $\mathrm{V}$ ). This very high value was the highest ever encountered in our studies, yet the corresponding $\mathrm{K} t$ value of 4.08 , while high, was not the highest value found (table IV).

\section{Discussion}

These studies show quite clearly that newborn infants of normal mothers do not remove glucose from the plasma following a glucose load as quickly as do infants of insulin-treated diabetic mothers. There is, however, some overlap between the groups when this removal is expressed as the 'total index', Kt. In an earlier study BAIRD and FARQUHAR [2] showed this difference in rate of glucose removal between the two groups, but JøRGENSEN et al. [11] were unable to demonstrate this. The specificity of the methods used to determine glucose could explain this difference. A glucose oxidase method was used by BAIRD and FARQUHAR as in this study, while the Hagedorn-Jensen method was used by JøRGENSEN et al. Infants of non-insulin-treated diabetics, on the contrary, did not differ significantly from those of normal mothers in their ability to remove glucose from the plasma.

Bowre et al. [3] demonstrated an increased rate of glucose removal (i.e., a higher $\mathrm{Kt}$ ) in infants of normal mothers in the second hour in comparison with the first after receiving glucose intravenously. This was found to be true in 70 percent of the infants of normal mothers in the present study but did not occur in any infants of the insulin-treated group and in only one infant from the group in which the diabetes was controlled by dietary restrictions only. In the groups of infants of diabetic mothers, the rate of removal usually decreased over the second part of the glucose tolerance test. It is noteworthy that these two groups of infants of diabetic mothers resembled each other closely in exhibiting marked hypoglycemia in the preglucose 
load period and, in the second part of the tolerance test, by their lack of ability to remove glucose quickly, but they differed widely in their ability to remove glucose in the first 60 minutes after administration of the intravenous load. Whether this difference reflects treatment with insulin, stage of development or the severity of the mothers' diabetes cannot be answered at present.

Maternal antibodies to insulin interfere with the immunoassay of insulin in the infants of insulin-treated diabetic mothers and make doubtful the measurements reported [10]. After allowing for this, a feature of the response of these infants to intravenous glucose is the single-phased release of insulin with a maximum at two minutes after administration of the glucose. This is not the case in infants of normal mothers whose insulin response to the glucose load is polyphasic. They show peak values for insulin on more than one occasion but with the maximum value usually being found at about 60 minutes after the glucose injection. The infants of insulin-independent diabetics exhibit a peak insulin value at two minutes; this is usually the maximum value reached, but high values and smaller peak values are often found later in the glucose tolerance test.

The high levels of insulin found in the plasma of some infants over long periods of time following administration of glucose raises the question of whether these levels are the result of a continuous, prolonged release of insulin, in response to a continuing stimulus, or a lack of the appropriate mechanisms for removing it from the circulation. The relatively large decreases in insulin levels occasionally found from one specimen to the next suggest that mechanisms for removal of insulin do exist.

The response of insulin to the glucose load is reflected in the $\mathrm{Kt}$ values found in the three groups. The initial high rate of glucose removal is preceded by a high insulin level two minutes after glucose injection in the infant of the insulin-treated diabetic mother, while the increased rate of glucose removal in the infants of normal mothers follows the increased levels of insulin found about one hour after administration of glucose. The changes in $\mathrm{Kt}$ which occur in the infants of insulinindependent mothers can, in individuals but not in all, be linked with the changes in insulin levels in plasma. These babies seem to have a relative insensitivity to insulin because, although the initial release of insulin may be large, the rate of glucose removal does not approach that usually found in the infants of the insulintreated diabetic group. However, in the case of Baby No.3534/66, whose mother was not recognized as a diabetic, the extremely large insulin release was associated with a high $\mathrm{Kt}$ value. Insulin is obviously not the only factor affecting the removal of glucose from the plasma of the newborn infant. The lack of a close relation between the size of the insulin response and the $\mathrm{Kt}$ value (and vice versa) in any individual subject has also been shown in adults [13].

The relation between the rate of glucose removal and insulin levels has been shown in newborn infants of normal mothers by BowIE et al. [3] and FARQUHAR [7], who administered both glucose and insulin to these babies and demonstrated an increased rate of glucose removal. The present study shows that increases in $\mathrm{Kt}$ are associated with increases in insulin levels in plasma and that infants of normal mothers are capable of releasing large amounts of insulin in response to hyperglycemia. This fact was not apparent from the earlier work of BAIRD and FARQUHAR [2] nor was it shown to be of such magnitude and duration by JøRGENSEN $e t$ al. [11] since in both the studies, the number of observations made on each infant was small. The period of time after glucose administration was short.

The infant of the normal mother is able to deal more readily with a glucose load if stimulated by a priming load [3]. This simulates the situation which occurs in infants of diabetic mothers, for they have probably received multiple priming loads while still in utero. Adults, too, respond more readily to a second glucose dose, for the insulin response to the second dose raises the level of insulin in the plasma above that produced by the first dose; they do not respond as readily to the second dose when the insulin level has had time to return to normal or when the insulin response to the first dose of glucose exceeds that caused by a second dose [13]. The slower rate of glucose removal in the infants of the insulin-independent mothers, compared with that of the infants of insulin-treated mothers, may reflect prior excessive stimulation of the pancreatic islets in the latter group. These findings favor the hypothesis that the hyperinsulinism of the infant of the diabetic mother is the result of the hyperglycemia of the mother which stimulates the islet cells of the fetus to produce insulin. The infant of the normal mother, and possibly to a lesser extent that of the insulin-independent diabetic mother, is on the contrary protected in utero by the homeostatic mechanisms controlling the mother's blood glucose level. This protection, however, would seem to be relative, because 80 percent of infants of normal mothers in the present study immediately released insulin when stimulated with glucose and some of the responses were large. In general, this group lags in the release of insulin in response to a hyperglycemic stimulus; this suggests that large amounts of insulin are not immediately available for release from the islet cells. Probably, as in adults [13], it is the capacity of the islets to respond to the hyperglycemia which determines the shape and height of the insulin response to intravenous glucose.

Thus, in the early neonatal period when homeostatic mechanisms for glucose metabolism are poorly ad- 
justed, glucose is the stimulus to insulin release. The removal of glucose from the plasma however does not depend upon the presence of insulin alone but may reflect in large part the in utero experience of the individual.

\section{Summary}

This work confirms that newborn infants of normal mothers remove glucose from plasma much more slowly than do newborn infants of insulin-treated diabetic mothers, but they do not differ greatly from newborn infants of insulin-independent diabetic mothers in this respect.

It also confirms that most newborn infants of normal mothers exhibit an increased rate of removal of glucose from the plasma about one hour after receiving glucose by intravenous administration. This increased rate is shown to occur at a time when levels of insulin in plasma are elevated.

The 'total index' $(\mathrm{Kt})$ in newborn infants of normal and diabetic mothers is shown to be related to the plasma insulin levels.

The newborn infants of normal mothers are, like those of diabetic mothers, capable of releasing insulin in response to hyperglycemia.

\section{References and Notes}

1. Amatuzio, D.S.; Stutzman, F.L.; Vanderbilt, M.J. and NesBitT, S.: Interpretation of the rapid intravenous glucose tolerance test in normal individuals and in mild diabetes mellitus. J. clin. Invest. 32: 428 (1953).

2. BAIRD, J.D. and FARQUHAR, J.W.: Insulin-secreting capacity in newborn infants of normal and diabetic women. Lancet 1: 71 (1962).

3. Bowie, M.D.; Mulligan, P.B. and Schwartz, R. : Intravenous glucose tolerance in the normal newborn infant: the effects of a double dose of glucose and insulin. Pediatrics 31: 590 (1963).

4. Data Sheet 5581: The immunoassay of insulin using iodinated insulin- $\mathrm{I}^{125}$ or $-\mathrm{I}^{\mathbf{1 3 1}}$ and insulin binding reagent (The Radiochemical Centre, Amersham 1965).

5. Duncan, L.J.P.: The intravenous glucose tolerance test. Quart.J.exp. Physiol. 41: 85 (1956).

6. FARQUHAR, J.W.: The significance of hypoglycaemia in the newborn infant of the diabetic woman. Arch. Dis. Childh. 31: 203 (1956).

7. FARQUHAR, J.W.: The influence of maternal diabetes on foetus and child; in Recent advances in paediatrics (ed. GaIrdNer, D.), 3rd ed., chapter 6, pp. 121-153 (Churchill, London 1965).
8. Farquhar, J.W. et Isles, T. E.: Glycémies et comportement clinique chez les nouveau-nés de mères normales et diabétiques. Journées Annuelles de Diabétologie de l'Hôtel-Dieu, p. 99 (Flammarion, Paris 1967).

9. Hales, C. N. and Randle, P.J.: Immunoassay of insulin with insulin antibody precipitate. Biochem. J. 88: 137 (1963).

10. IsLes, T.E. and Farquhar, J.W.: The effect of endogenous antibody on insulin-assay in the newborn infants of diabetic mothers. Pediat. Res. 1: 110 (1967).

11. Jørgensen, K.R.; Deckert, T.; Pedersen, L. M. and Pedersen, J.: Insulin, insulin antibody and glucose in plasma of newborn infants of diabetic women. Acta endocr. 52: 154 (1966).

12. RaAbo, E. and Terkildsen, T. G.: On the enzymatic determination of blood glucose. Scand.J. clin. Lab. Invest. 12: 402 (1960).

13. SAmols, E. and Marks, V.: Interpretation of the intravenous glucose test. Lancet 1: 462 (1965).

14. Scopes, J.W. and Ahmed, I. : Range of critical temperatures in sick and premature newborn babies. Arch. Dis. Childh. 41: 417 (1966).

15. Yalow, R.S. and Berson, S.A.: Immunoassay of endogenous plasma insulin in man. J. clin. Invest. 39: 1157 (1960).

16. In each case time was allowed for placental drainage to the baby. Infants delivered per vaginam were held below the level of the mother for 2 minutes before the cord was clamped. Those born bysection were delivered with the placenta which was then raised above the baby for 2 minutes before the cord was clamped. In both situations the cord was lightly stripped toward the infant.

17. An aerosolised spray of polymixin and bacytracin.

18. The term 'insulin' means immunologically reactive insulin under the conditions of the method used.

19. We gratefully acknowledge the support of Professor J.O. Forfar in this study and wish to record our thanks to Miss M.STApless, Labour Ward Supervisor of the Simpson Memorial Maternity Pavilion, for the unstinted and cheerful nursing help which made this study possible. We also thank the Board of Management of the Royal Infirmary for a research grant, Miss SANDRA RoBERTSON for technical assistance, Miss Elizabeth MeIklejohn and Miss Bernice Grichton for much secretarial help, and the mothers who entrusted their babies to us.

20. Requests for reprints should be addressed to: J.W. FARQUhar, M.D., Department of Child Life and Health, University of Edinburgh, 17 Hatton Place, Edinburgh 9 (Scotland). 